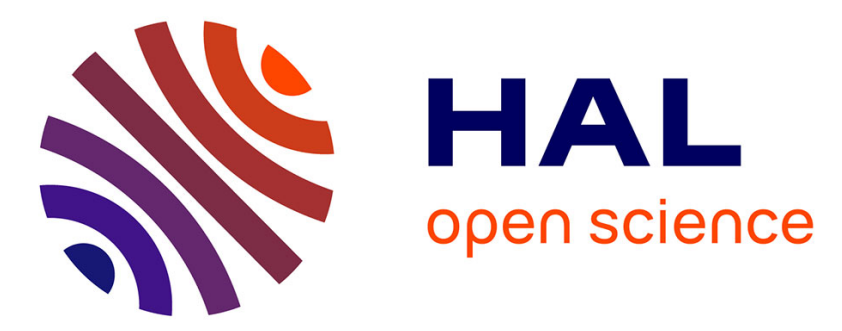

\title{
Interdisciplinary European Guidelines on Metabolic and Bariatric Surgery
}

Martin Fried, Volkan Yumuk, Jean-Michel Oppert, Nicola Scopinaro, Antonio J. Torres, Rudolf Weiner, Yuri Yashkov, Gema Frühbeck

\section{- To cite this version:}

Martin Fried, Volkan Yumuk, Jean-Michel Oppert, Nicola Scopinaro, Antonio J. Torres, et al.. Interdisciplinary European Guidelines on Metabolic and Bariatric Surgery. Obesity Facts, 2013, 6 (5), pp.449 - 468. 10.1159/000355480 . hal-01590927

\section{HAL Id: hal-01590927 \\ https: / hal.sorbonne-universite.fr/hal-01590927}

Submitted on 20 Sep 2017

HAL is a multi-disciplinary open access archive for the deposit and dissemination of scientific research documents, whether they are published or not. The documents may come from teaching and research institutions in France or abroad, or from public or private research centers.
L'archive ouverte pluridisciplinaire HAL, est destinée au dépôt et à la diffusion de documents scientifiques de niveau recherche, publiés ou non, émanant des établissements d'enseignement et de recherche français ou étrangers, des laboratoires publics ou privés.

\section{(c)(1)}

Distributed under a Creative Commons Attribution| 4.0 International License 


\title{
Clinical Information
}

\section{Interdisciplinary European Guidelines on Metabolic and Bariatric Surgery}

\author{
Martin Fried ${ }^{a}$ Volkan Yumuk ${ }^{b}$ Jean-Michel Oppert ${ }^{c} \quad$ Nicola Scopinaro $^{d}$ \\ Antonio J. Torres ${ }^{\mathrm{e}}$ Rudolf Weiner ${ }^{f}$ Yuri Yashkov ${ }^{g}$ Gema Frühbeck $^{\mathrm{h}}$ \\ aOB Klinika, Centre for Treatment of Obesity and Metabolic Disorders, 1st Faculty \\ of Medicine, Charles University, Prague, Czech Republic, ${ }^{b}$ Division of Endocrinology, \\ Metabolism and Diabetes, Istanbul University Cerrahpasa Medical Faculty, Istanbul, Turkey, \\ 'Department of Nutrition, Heart and Metabolism Division, Pitie Salpetriere University \\ Hospital (AP-HP) University Pierre et Marie Curie-Paris 6, Institute of Cardiometabolism \\ and Nutrition (ICAN) Paris, France, 'dMedical School, University of Genoa, Genoa, Italy, \\ e Department of Surgery Complutense University of Madrid, Hospital Clinico 'San Carlos', \\ Madrid, Spain, ${ }^{f}$ Sachsenhausen Hospital and Centre for Minimally Invasive Surgery, Johan \\ Wolfgang Goethe University, Frankfurt/M., Germany, ${ }^{9}$ Obesity Surgery Service, Centre of \\ Endosurgery and Lithotripsy Moscow, Russia, h Department of Endocrinology and Nutrition, \\ Clínica Universidad de Navarra, CIBERobn, Instituto de Salud Carlos III, Pamplona, Spain
}

\section{Key Words}

Guidelines · Bariatric surgery · Metabolic surgery · Interdisciplinary · Indications · Contraindications · Follow-up

\begin{abstract}
In 2012, an outstanding expert panel derived from IFSO-EC (International Federation for the Surgery of Obesity - European Chapter) and EASO (European Association for the Study of Obesity), composed by key representatives of both Societies including past and present presidents together with EASO's OMTF (Obesity Management Task Force) chair, agreed to devote the joint Medico-Surgical Workshop of both institutions to the topic of metabolic surgery as a pre-satellite of the 2013 European Congress on Obesity (ECO) to be held in Liverpool given the extraordinarily advancement made specifically in this field during the past years. It was further agreed to revise and update the 2008 Interdisciplinary European Guidelines on Surgery of Severe Obesity produced in cooperation of both Societies by focusing in particular on the evidence gathered in relation to the effects on diabetes during this lustrum and the subsequent changes that have taken place in patient eligibility criteria. The expert panel composition allowed the coverage of key disciplines in the comprehensive management of obesity and obesity-associated diseases, aimed specifically at updating the clinical guidelines to reflect current knowledge, expertise and evidence-based data on metabolic and bariatric surgery.


Fried et al.: Interdisciplinary European Guidelines on Metabolic and Bariatric Surgery

\section{Introduction}

The term 'globesity' describes the world-wide epidemic that currently affects both developed and developing countries [1-3]. In 2008, according to the World Health Organization (WHO), 1.4 billion adults, 20 years of age and older, were overweight with an estimated 500 million adults world-wide being obese (over 200 million men and nearly 300 million women) [2-4]. In 2009-2010 in the USA the age-adjusted prevalence of obesity was $35.5 \%$ among adult men and $35.8 \%$ among adult women [5] with the prevalence of obesity in children and adolescents being $16.9 \%$ [6]. Noteworthy, the prevalence of obesity has tripled since the 1980s in many countries of the WHO European Region with overweight and obesity affecting $50 \%$ of the population in the majority of European countries [2-4]. It has been estimated that $60 \%$ of the world's population, i.e., 3.3 billion people, could be overweight $(2.2$ billion) or obese (1.1 billion) by 2030 if recent trends continue [7].

In spite of excess weight being considered the fifth leading risk for world-wide deaths according to the WHO, it has not been possible to successfully curb the obesity epidemic with more than 40 million children under the age of 5 being overweight in 2010 [3]. Moreover, severe obesity (i.e., a BMI $>35 \mathrm{~kg} / \mathrm{m}^{2}$ ) represents a quickly growing segment of the epidemic in which the negative effects on health and disability are especially marked. In addition, obesity not only disproportionately affects the disadvantaged segments of the population, but these groups experience the most relevant increases in obesity prevalence. In the USA individuals with a BMI $>35 \mathrm{~kg} / \mathrm{m}^{2}$ represent $15 \%$ of the adult population [5]. Excess weight drastically elevates a person's risk of developing a number of non-communicable diseases, like diabetes, hypertension, stroke, dyslipidaemia, sleep apnoea, cancer, non-alcoholic steatohepatitis and other serious co-morbidities. The WHO emphasizes that $44 \%$ of the type 2 diabetes mellitus (T2DM) burden, 23\% of the ischaemic heart disease burden and around $7-41 \%$ of certain cancer burdens are attributable to overweight and obesity $[3,4]$. In the majority of European countries, overweight and obesity are responsible for about $80 \%$ of cases of T2DM, $35 \%$ of ischaemic heart disease and $55 \%$ of hypertensive disease among adults [4]. In addition, a range of debilitating conditions such as osteoarthritis, respiratory difficulties, gallbladder disease, infertility and psychosocial problems, which lead to reduced life expectancy, quality of life and disability, are extremely costly in terms of both absence from work and use of health resources $[2,4,8,9]$. Noteworthy, the lifespan of severely obese individuals is decreased by an estimated 5-20 years depending on gender, age and race [10].

At present, approximately $65 \%$ of the world's population inhabits countries where overweight and obesity kill more people than underweight [2-4]. The WHO highlights that obesity is responsible for $10-13 \%$ of deaths in different parts of the world [2-4]. A systematic analysis with pooled data from 19 prospective studies adjusted for age, study, physical activity, alcohol consumption, education and marital status, comprising 1.46 million white adults and over 160,000 deaths, showed that overall, for men and women combined, for every 5-unit increase in BMI, a 31\% increase in risk of death was observed [11]. A recent meta-analysis focusing on all-cause mortality with the inclusion of nearly 3 million people (and encompassing 270,000 deaths) reported that, relative to normal weight, both all grades of obesity (i.e., a BMI $>30$ $\mathrm{kg} / \mathrm{m}^{2}$ ) and grades 2 and 3 obesity (i.e., a BMI $35-40 \mathrm{~kg} / \mathrm{m}^{2}$ and $>40 \mathrm{~kg} / \mathrm{m}^{2}$, respectively) were associated with significantly higher all-cause mortality [12].

Bariatric surgery has proven to be the most effective mode of treatment of the morbidly obese patients, with recent long-term studies providing evidence of a substantial reduction of mortality in bariatric surgery patients as well as decreased risk of developing new healthrelated co-morbidities, together with decreased health care utilization and drop in direct health care costs $[10,13]$. 
Bariatric surgery is an established and integral part of the comprehensive management of morbidly obese patients. These guidelines were created through the interdisciplinary effort of key opinion leaders from international medical and surgical societies (International Federation for the Surgery of Obesity (IFSO), International Federation for the Surgery of Obesity - European Chapter (IFSO-EC), European Association for the Study of Obesity (EASO)) [14]. The aim of the guidelines is to provide physicians, health care practitioners, health care policy makers and health care providers and insurance companies with essential elements of good clinical practice in the treatment of obesity.

Scientific evidence level data to support conclusions of this panel of experts were systematically obtained from databases such as Medline (PubMed) and the Cochrane Library.

Searches spanned from January 1980 to May 2013 and were carried out with the help of an expert in library science, together with a clinical expert with experience in systematic reviews.

The key search words were obesity, obesity surgery, morbid obesity, surgical treatment, bariatric surgery, morbid obesity surgery, gastroplasty, gastric bypass, gastric plication, intestinal bypass, Roux-en-Y, gastric banding, biliopancreatic diversion, duodenal switch, biliopancreatic bypass, obesity/morbid obesity treatment outcomes, obesity/morbid obesity follow-up, obesity/morbid obesity complications, nutrition, psychology. Some of the evidence level data was also retrieved from the following publications: Commonwealth of Massachusetts Betsy Lehman Center for Patient Safety and Medical Error Reduction Expert Panel on Weight Loss Surgery [15], Obesity Surgery Evidence-Based Guidelines of the European Association for Endoscopic Surgery (EAES) [16], Maggard etal.'s Meta-Analysis: Surgical Treatment of Obesity [17] and Laville et al.'s Recommendations Regarding Obesity Surgery [18], and the Clinical Practice Guidelines for the Perioperative Nutritional, Metabolic, and Nonsurgical Support of the Bariatric Surgery Patient - 2013 Update by Mechanick et al. [19].

The recommendations of the panel are supported by the best available evidence, which includes all evidence levels (randomized controlled trials (RCTs), systematic reviews of cohort studies, observational outcomes studies and expert opinion). To grade the quality of evidence, the panel adopted 'Oxford Centre for Evidence-Based Medicine classification system based on levels of evidence and 'grades of recommendations according to the study designs and critical appraisal of prevention, diagnosis, prognosis, therapy and harm studies.

The Oxford classification system has four evidence levels (EL):

- Level A: consistent RCT, cohort study, all or none, clinical decision rule validated in different populations.

- Level B: consistent retrospective cohort, exploratory cohort, ecological study, outcomes research, case-control study; or extrapolations from level A studies.

- Level C: case-series study or extrapolations from level B studies.

- Level D: expert opinion without explicit critical appraisal, or based on physiology, bench research or first experience/principles case reports.

\section{Indications for Bariatric Surgery}

Patients in age groups from 18 to 60 years:

1. With BMI $\geq 40 \mathrm{~kg} / \mathrm{m}^{2}$ (EL A, B, C [14, 19-38]).

2. With BMI $35-40 \mathrm{~kg} / \mathrm{m}^{2}$ with co-morbidities in which surgically induced weight loss is expected to improve the disorder (such as metabolic disorders, cardiorespiratory disease, severe joint disease, obesity-related severe psychological problems) (EL A, B, D [39-44]). 
3. BMI criterion may be the current BMI or previously maximum attained BMI of this severity. Note that:

a) Weight loss as a result of intensified treatment before surgery (patients who reach a body weight below the required BMI for surgery) is not a contraindication for the planned bariatric surgery.

b) Bariatric surgery is indicated in patients who exhibited a substantial weight loss in a conservative treatment programme but started to gain weight again, even if the required minimum indication weight for surgery has not yet been attained again.

To be considered for surgery, patients should have failed to lose weight or to maintain long-term weight loss, despite appropriate surgical and/or non-surgical comprehensive medical care (EL B, D [21,38]).

c) Consideration should be given to reducing the BMI threshold by 2.5 for individuals of Asian genetic background and to the balance between genetic and environmental/dietary factors.

Patients should have shown their compliance with scheduled medical appointments.

\section{Bariatric Surgery and T2DM}

T2DM can be viewed as a reversible disease. Bariatric surgery has clearly confirmed to be beneficial in T2DM remission. Bariatric surgery contributes to improved beta cell function in patients with BMI $>35 \mathrm{~kg} / \mathrm{m}^{2}$ (EL A [45-47]). (Note that throughout the guidelines there are different $\mathrm{HbA1}$ c cut-offs stated in certain sections/paragraphs. However, different cut-offs are pertinent to statements outlining different treatment outcomes, for example success of post-bariatric improvement of T2DM patients versus 'partial' or 'complete' remission in T2DM patients, etc.).

Surgically induced improvement of T2DM may be considered effective if:

- Post-operative insulin dose $\leq 25 \%$ of the pre-operative one

- Post-operative oral anti-diabetic treatment dose $\leq 50 \%$ of the pre-operative one

- Post-operative reduction in HbA1c $>0.5 \%$ within 3 months or reaching $<7.0 \%$.

- Patients with BMI $\geq 30$ and $<35 \mathrm{~kg} / \mathrm{m}^{2}$ with T2DM may be considered for bariatric surgery on an individual basis, as there is evidence-based data supporting bariatric

surgery benefits in regards to T2DM remission or improvement (EL A, B, C, D [48-60]).

However there is not yet available large enough number of high evidence level data to unquestionably support a clear, long-term benefit, especially for merely and self-standing surgical treatment/control of glycaemia, dyslipidaemia and/or other metabolic diseases.

\section{Bariatric Surgery in Children/Adolescents}

Indication for bariatric surgery in adolescents and children could be considered in centres with extensive experience of such treatment in adults and who are able to offer a true multidisciplinary approach, which involves paediatric skills relating to surgery, dietetics and psychological management.

In adolescents with severe obesity, bariatric surgery can be considered if the patient (EL C, D [61-68]):

1. Has a BMI $>40 \mathrm{~kg} / \mathrm{m}^{2}$ (or 99.5th percentile for respective age) and at least one co-morbidity. 
2.Has followed at least 6 months of organized weight reducing attempts in a specialized centre.

3. Shows skeletal and developmental maturity.

4. Is capable to commit to comprehensive medical and psychological evaluation before and after surgery.

5. Is willing to participate in a post-operative multidisciplinary treatment programme.

6. Can access surgery in a unit with specialist paediatric support (nursing, anaesthesia, psychology, post-operative care).

Bariatric surgery can be considered in genetic syndromes such as Prader-Willi syndrome only after careful consideration of an expert medical, paediatric and surgical team.

\section{Bariatric Surgery in Those Aged above 60}

The proof of a favourable risk benefit must be demonstrated in elderly or ill patients before surgery is contemplated in such individuals.

In elderly patients, the primary objective of surgery is to improve quality of life, even though surgery is unlikely to increase lifespan [69].

\section{Contraindications Specific for Bariatric Surgery}

1. Absence of a period of identifiable medical management.

2. Patient who is unable to participate in prolonged medical follow-up.

3. Non-stabilized psychotic disorders, severe depression, personality and eating disorders, unless specifically advised by a psychiatrist experienced in obesity.

4. Alcohol abuse and/or drug dependencies.

5. Diseases threatening life in the short term.

6. Patients who are unable to care for themselves and have no long-term family or social support that will warrant such care.

Specific Exclusion Criteria for Bariatric Surgery in the Treatment of T2DM

1. Secondary diabetes.

2. Antibodies positive (anti-GAD or anti-ICA) or C-peptide $<1 \mathrm{ng} / \mathrm{ml}$ or unresponsive to mixed meal challenge.

\section{Patient Pre-Operative Evaluation}

A decision to offer surgery should follow a comprehensive interdisciplinary assessment. The core team providing such assessment should optimally consist of the following specialists experienced in obesity management and bariatric surgery (EL B,C, D [16, 40, 70-77]):

- physician,

- surgeon,

- anaesthetist,

- psychologist or psychiatrist,

- nutritionist and/or dietitian,

- nurse practitioner / social worker.

Patients indicated for bariatric surgery should undergo routine pre-operative assessment as for any other major abdominal surgery. 
Fried et al.: Interdisciplinary European Guidelines on Metabolic and Bariatric Surgery

Pre-operative management should include assessment of general health and nutritional status as follows

- explanation of the dietary changes that are required after surgery,

- optimizing treatment of co-morbidities to reduce the risks of the surgical procedure,

- assessment of patient motivation and willingness to adhere to follow-up programmes,

- ensuring that the patient is fully informed on the benefits, consequences and risks of the surgical options and the necessity of lifelong follow-up,

- ensuring that the patient understands the potential (limited) outcomes of surgery,

- ensuring that the patient can give truly informed consent including a statement on risks of the surgery and acceptance of life style modification, including behavioural changes and follow-up compliance.

In addition to the routine pre-operative assessment as for any other major abdominal surgery, the patient should undergo further assessment for (depending on the planned bariatric procedure and clinical status of the patient) (EL A, B, C, D [16, 78-92]):

- sleep apnoea syndrome and pulmonary function,

- metabolic and endocrine disorders, lipids, TSH, etc.,

- gastro-oesophageal disorders (Helicobacter pylori, etc. ),

- bone density,

- body composition,

- resting energy expenditure.

\section{Psychological Support}

\section{Pre-Operative Phase}

Psychological assessment of behavioural, nutritional, familial and personality factors should be an integral part of the patient's pre-operative evaluation (EL C [93-99]).

The purpose of the psychosocial evaluation for weight loss surgery is not merely diagnostic, but to enhance the safety and efficacy of surgical treatment by identifying areas of potential vulnerability, challenges and strengths in order to create an individually tailored treatment plan.

Pre-operative psychological evaluation should always include assessment of psychopathology such as personality examination as well as assessment of his/her expectation/motivation, diet history, lifestyle (i.e. nutritional behaviour, physical activity habits, life conditions), social support network. Pre-operative evaluation enables identification of interventions that can enhance long-term compliance and weight maintenance (i.e., crisis intervention, psychological support, psychotherapy, etc.) (EL D [100]). The goal is to enhance patients' motivation and ability to comply with nutritional, behavioural and psychosocial changes before and after bariatric surgery. Pre-operative examination leverages psychological support in case of patient's psychological disorder relapse post-operatively (depression, anxiety etc.) (EL C, D [101-104]).

Pre-operative evaluation should detect potential psychological contraindications to surgery, such as severe eating disorders and others highlighted in 'Contraindications Specific for Bariatric Surgery' (see above).

\section{Post-Operative Psychological Support}

Eating pathologies, such as binge eating disorder (BED) increase the risk of and lower weight loss and weight regain after some bariatric procedures (EL C [105-110]). Presence of 2 and more psychiatric/mental disorders increases the risk of inadequate weight loss after both purely food restrictive as well as metabolic type of procedures (EL B [111-115]). 
Pre-operative identification of psychological risk factors associated with lower postoperative compliance, inadequate weight loss, alcohol or drug dependencies, eating pathologies and others should lead to post-operative interventions through implementing a selfmonitoring strategy in higher-risk patients.

\section{Surgical Techniques Overview}

In the past several years better understanding of substantial metabolic changes induced by different surgical interventions to the alimentary tract was achieved. Therefore, the former classification of operations according to their influence on food ingestion, defined as limiting stomach capacity (restrictive), limiting absorption of nutrients (malabsorptive) or combined procedures does not appropriately reflect the current level of knowledge about early and weight-independent metabolic effects of these operations. Nowadays, most of the standard surgical interventions are being mostly referred to as metabolic operations. The focus when treating obese patients is gradually shifting from the primary goal of weight loss outcomes to the metabolic effects of the operations (EL A, B, C, D [116-128]).

Standard bariatric and metabolic procedures that are currently available for patients requiring weight loss and/or metabolic control are:

- adjustable gastric banding (AGB),

- sleeve gastrectomy (SG),

- Roux-en-Y gastric bypass (RYGB),

- biliopancreatic diversion (BPD),

- BPD/duodenal switch (BPD-DS).

Recent procedures in which long-term outcome data is not yet available include:

Laparoscopic gastric plication (LGP) in which infolding of the greater curvature of the stomach leads to tubularizing the stomach through intraluminal tissue fold. The current evidence on laparoscopic gastric plication for severe obesity raises no major safety concerns in short-to-medium term but more evidence is needed about the long-term efficacy of the procedure (EL B [129-134]).

- The 'omega loop gastric bypass' involves laparoscopic construction of elongated gastric pouch and a loop gastric bypass with distal diversion. Omega loop gastric bypass is so far controversial for its potential long-term risks. Most of the evidence on the omega gastric bypass comes from descriptive reports and case series, and more evidence-based data is needed to enable appropriate evaluation of safety and efficacy of the procedure.

Procedures that are under investigation:

- Single-anastomosis duodeno-ileal bypass (SADI) with sleeve gastrectomy is a modified duodenal switch operation. This procedure is performed so far only in the framework of clinical trials, and no wider spread of the procedure is recommended until evidencebased data are available [135].

A strictly 'investigational' approach is recommended for different 'intestinal interposition' operations:

- Endoluminal innovative procedures.

The currently explored endoluminal novel procedural techniques, devices and technologies are in various stages of technical development and are an experimental or clinical application for both the primary or revisional treatment of obesity. These novel technologies have no evidence-based data support yet and should be limited to clinical trials conducted under ethical guidelines and under institutional review board (IRB) approvals only.

However, it is expected that some of the investigational procedures will impact the future decision making in the treatment of obesity. 
Fried et al.: Interdisciplinary European Guidelines on Metabolic and Bariatric Surgery

\section{Assigning a Patient to a Particular Bariatric Procedure}

At this moment, there is insufficient evidence-based data to suggest how to assign a patient to a specific bariatric/metabolic procedure with no evidence in favour of any particular procedure.

A laparoscopic technique should be considered as the preferable approach to the operation in bariatric surgery, providing no contraindications for the laparoscopic approach are present (EL A [136]).

Among others, pre-operative factors that could influence the choice of the type of operation are:

- BMI,

- age,

- gender,

- body fat distribution,

- T2DM

- duration of T2DM

- pre-op levels of HbA1c

- multi-drug anti-diabetic treatment

- fasting C-peptide levels,

- dyslipidaemia,

- low IQ,

- significant hiatal hernia,

- gastroesophageal reflux disease (GERD),

- patient's expectations/realistic goals,

- presence of eating disorders,

- presence of long-term treatment for a coexisting disease or condition for which absorption and pharmacokinetics are of major concern.

The expected average impact on improvement of metabolic status, improvement or remission of T2DM, weight loss, and weight maintenance is increasing with the following procedures in the following order: AGB, LSG, RYGB, BPD/DS, BPD.

On the contrary, the surgical complexity and potential surgical and long-term metabolic risks of procedures decrease in reverse order (EL A, B, C, D [17, 137-162]).

The early weight-independent metabolic effects on HbA1c, LDL cholesterol, blood pressure, prevention and reduced cardiovascular risks of some of the procedures were already demonstrated in several studies; however, the exact mechanism of action of different surgical interventions has to be explored in detail and is not completely defined yet (EL A, B, C, D) [163-167].

Better understanding of various mechanisms of action of these operations may contribute to personalized treatment and more precise assignment of different procedures to individual patients [168].

The procedures should be performed at interdisciplinary obesity management centres with appropriately trained staff and adequate equipment (see above).

In all situations, the bariatric surgeon's experience is a key issue. It is not advisable to practise bariatric techniques on an occasional basis.

If the patient is expected to benefit more from a particular procedure not available in a specific centre, he/she should be referred to a centre/surgeon with adequate bariatric experience in that procedure (EL B, D [30, 170-176]).

As a result of successful bariatric treatment with substantial weight loss, further treatment (such as plastic/reconstructive surgery) might be required. 


\section{Follow-Up}

Morbid obesity is a lifelong disease. The treating physician and surgeon are responsible for the treatment of co-morbidities before the operation and for the follow-up after the operation.

Complementary follow-up pathways (surgical and medical) should be provided to all patients, ideally in part through interdisciplinary joint clinics. The surgeon is responsible for all possible short-and long-term events directly related to the operation.

The medical physician will be responsible for the long-term post-surgery follow-up and management of obesity and obesity-related diseases and operation-related non-surgical consequences.

Treatment outcome is significantly dependent, among other factors, on patientcompliance with long-term follow-up.

Patients attending support groups after bariatric/metabolic surgery show enhanced weight loss and other treatment outcomes, especially those receiving RYGB and gastric banding (EL C). Patients should be repeatedly educated about staged meal progression dependent on the time elapsed after surgery and based on the type of surgical procedure they underwent (EL A, B, C, D [177-185]). Patients should also be informed that an excessive number and size of meals will probably result in lower weight loss.

They should be advised on the general importance of:

- adequate protein intake in order to prevent excessive lean body mass loss,

- avoidance of ingestion of concentrated sweets to prevent dumping syndrome, especially after RYGB and BPD,

- preferable use of crushed and/or rapid release medication (EL B, D [186, 187]),

- the health benefits of regular physical activity / exercise that may need specific advice.

In case of T2DM patients, use of anti-diabetic medication and/or insulin should be adjusted with no delays post-operatively in order to minimize risks of hypoglycaemia.

Criteria for assessment of the effect of bariatric surgery on remission of T2DM [58]:

- Partial remission: hyperglycaemia below diagnostic thresholds for diabetes (HbA1c > $6 \%$, but $<6.5 \%$, FPG $100-125 \mathrm{mg} / \mathrm{dl}$ ), at least 1 -year duration, no active pharmacological therapy or on-going procedures.

- Complete remission: Normal glycaemic measures (HbA1c normal range $(<6 \%)$, FPG $<$ $100 \mathrm{mg} / \mathrm{dl}$ ), at least 1-year duration, no active pharmacological therapy or on-going procedures.

- Prolonged remission: Complete remission of at least 5-year duration.

Criteria for assessment of effect of bariatric surgery on optimization of metabolic status and some other co-morbid conditions [58]:

- HbA1c $\leq 6 \%$, no hypoglycaemia, total cholesterol $<4$ mmol/l, LDL-cholesterol $<2$ $\mathrm{mmol} / \mathrm{l}$, triglycerides $<2.2 \mathrm{mmol} / \mathrm{l}$, blood pressure $<135 / 85 \mathrm{mmHg},>15 \%$ weight loss, or lowering of $\mathrm{HbA} 1 \mathrm{c}$ by $>20 \%, \mathrm{LDL}<2.3 \mathrm{mmol} / \mathrm{l}$, blood pressure $<135 / 85 \mathrm{~mm} \mathrm{Hg}$ with reduced medication from pre-operative status.

In cases of postprandial hypoglycaemic symptoms, evidence for lowered blood glucose concurrent with symptoms should be looked for; patients should first be advised on dietary changes (low carbohydrate diets, regular meal times); second-line drug treatment may be considered, such as acarbose, calcium-channel antagonists, diazoxide, octreotide (EL C [188192].)

Special care must be taken for:

- The possible nutritional deficiencies such as vitamin, protein and other micronutrients.

- Adjustments of medical treatments, specifically treatment of obesity-related co-morbidities such as diabetes and hypertension, and avoidance of some types of pharmaco- 
Fried et al.: Interdisciplinary European Guidelines on Metabolic and Bariatric Surgery

therapy (e.g., non-steroidal and steroidal anti-inflammatory drugs), prevention of deep vein thrombosis (DVT) and/or pulmonary embolism is recommended for all bariatric patients through subcutaneous LMW heparin administration, leveraged with use of T.E.D. stockings, early post-operative ambulating and intra- and post-operative use of sequential compression devices (EL B, C, D [193-196]).

- Early detection and adequate treatment of gastrointestinal (GI) leaks in suspected patients (newly sustained tachycardia $>120$ pulses/min for at least $6 \mathrm{~h}$, fever, tachypnoea, newly established signs of hypoxia, increasing pain, elevated C-reactive protein) through upper GI X-ray or CT studies. Surgical revision (laparoscopy or laparotomy) may be considered and is justified in case of highly clinically suspicious cases, despite non-presence of some of the symptoms and/or even in negative upper GI studies (EL C [197-200]).

All patients after bariatric procedures require regular lifelong qualified surveillance.

Patients must have access to 24-hour emergency service provided by the operating centre.

In case severe GI symptoms are present and persistent (such as abdominal pain, nausea, vomiting, change in stools etc.) endoscopy and/or CT may be considered as the first diagnostic/ therapeutic option in order to evaluate potential presence of intestinal disease(s), bacterial overgrowth, ulcer disease, anastomotic problems, obstruction due to foreign body, etc.

The patient takes lifelong responsibility for adhering to the follow-up rules.

\section{Minimal Requirements for Follow-Up after Food Limitation Operations}

The patient should be provided with written information about the procedure and exact type of the received implant (if applicable) together with description of possible serious adverse effects.

\section{$A G B$}

- Follow-up during the first year should be at least every 3 months, starting 1 month postoperatively until a clinically satisfactory rate of weight loss is achieved, if necessary with repeated band fills. Thereafter follow-up should be at intervals of no more than 1 year.

- Follow-up should be carried out by the interdisciplinary team and should include dietary change/behavioural modification/physical activity interventions and encouragement as well as pharmacology support and surgical revision if appropriate.

- Metabolic and nutritional status should be regularly monitored to prevent vitamin and mineral deficiencies and allow appropriate supplementation, as well as to monitor response to surgery and weight loss and adjust concomitant drug treatment.

- Band adjustments should be performed according to the individual patient weight loss and the type of the implant:

- first inflation according to the type of the band,

- as a medical/clinical decision,

- by trained medical or paramedical staff with adequate experience (such as surgeon, medical physician, nurse practitioner, dedicated radiologist).

- Supplement of vitamins and micronutrients should compensate for their possible reduced intake.

$R Y G B$

- Check-up after 1 month, minimal follow-up every 3 months for the 1st year, every 6 months for the 2 nd year and annually thereafter. 
- Vitamin and micronutrient supplements (oral) should routinely be prescribed to compensate for their possible reduced intake and absorption.

- However, in addition, laboratory tests to evaluate the metabolic and nutritional status should also be carried out annually to include:

- fasting, glucose (+HbA1c in diabetics), liver function tests, renal function, vitamin B1, B9 (folates), B12, 25(OH) vitamin D3, ferritin, parathormone, albumin, Hb, $\mathrm{Ca} 2+$, checks, as well as basic blood cells, haemoglobin and electrolytes tests.

- As a result of these tests, it may be necessary to correct deficits by first oral supplementation or even parenteral administration of vitamins and micronutrients.

- In case of secondary lactose intolerance, supplementation with oral lactase is advised.

- In case of early dumping syndrome, hydration before meals is advised and the use of corn starch and/or low glycaemic index food supplements considered.

- In case of late dumping syndrome hypoglycaemia should be considered and the patient assessed and advised accordingly.

\section{Minimal Requirements and Recommendations for Follow-Up after Operations Limiting Absorption of Nutrients}

$B P D$

- Check-up after 1 month, followed by minimal follow-up every 3 months after the operation in the 1 st post-operative year, every 6 months in the 2 nd year, and annually thereafter.

- Laboratory tests are necessary to evaluate the evolution of metabolic and nutritional status and to adapt supplementation and drug treatment accordingly.

- Blood tests at 1, 4 and 12 months, thereafter annually:

- liver function tests (GPT, $\gamma$-GT),

- complete blood cell count, complete blood electrolytes tests,

- minimal nutritional parameters should be vitamin B12, 25(OH) vitamin D3, parathormone, bone alkaline phosphatase, ferritin, calcium, pre-albumin, albumin, transferrin, creatinine, prothrombin time (PPT), etc.

- Urine examination.

- Lifelong daily vitamin and micronutrient supplementation (vitamins should be administered in a water-soluble form):

- vitamin A, D, E and K

- calcium supplementation (preferably in food, calcium citrate, recommended total intake $2 \mathrm{~g}$ /day).

- Minimum advised protein intake of approximately $90 \mathrm{~g} /$ day.

- In addition, supplement of vitamins and micronutrients should compensate for their possible reduced intake and absorption and according to lab values.

- In a preventive regimen the supplementation can be administered orally.

- For correction of deficits, the supplementation can be administered parenterally, except for calcium.

- Proton pump inhibitors/histamine 2 receptor antagonists for the entire first post-operative year.

In case of excessive bloating, flatulence and/or foul-smelling stools, the recommended treatments are oral neomycin or metronidazole or pancreatic enzymes (EL A, B, C, D [201228]). 
Fried et al.: Interdisciplinary European Guidelines on Metabolic and Bariatric Surgery

\section{Failed Treatment}

To reinforce adherence to lifestyle changes and weight loss maintenance after bariatric surgery, regular contacts and lifelong follow-up with the obesity management centre are usually required.

Scientific evidence reveals that a certain number of bariatric patients will fail to lose weight or to maintain weight loss.

If medically indicated and if such a patient is willing, further bariatric surgery should be considered (EL B, C, D [229-242]).

\section{Conclusion}

All those who, on behalf of the scientific societies IFSO, IFSO-EC and EASO, partially re-wrote and up-dated the former 2008 Interdisciplinary European Guidelines on Surgery of Severe Obesity [14] realize that they have touched only basic issues of bariatric and metabolic surgery.

There are many other areas in this field that were deliberately left open or were not up-dated at this point. Among such areas are definitions of centres of excellence, bariatric surgeon's qualification and acceptance of the disease/reimbursement issues. These issues will be subject of the societies' future work. The authors hope that these guidelines will improve both medical and surgical care of severely obese patients and will contribute to better outcomes and increased patient safety in the long term.

\section{Disclaimer}

The consensus material in this document is a clinical guideline. It is therefore intended to promote and guide good clinical practice. It should not be construed as a substitute for, or as taking precedence over the duty of a clinician to conscientiously apply his/her knowledge and clinical skill to the best interests of a given patient $[243,244]$.

It may thus be fully correct to offer or agree treatment without this guidance. Clinicians may wish to document that they appraised patients clearly when proposing such treatment.

In applying this guidance clinicians are advised in each case to consider the strength of evidence for any given part of it.

IFSO-EC and EASO are committed to promoting reliance on operationalized and controlled data.

\section{Acknowledgements}

We thank V. Hainer, Institute of Endocrinology, 1st and 3rd Medical Faculty, Charles University, Prague, Czech Republic, A. Basdevant, INSERM, U755 Nutriomique, University of Paris and AP-HP, Hôtel-Dieu Hospital, Paris, France, H. Buchwald, Department of Surgery, University of Minnesota, MN, USA, M. Deitel, CRCSC, FICS, FACN, Obesity Surgery, Toronto, Canada, N. Finer, Wellcome Clinical Research Facility, Addenbrooke's Hospital, University of Cambridge School for Clinical Medicine, UK, J.W.M. Greve, Department of Surgery University Hospital Maastricht, The Netherlands, F. Horber, Clinik Lindberg AG, Winterthur, Switzerland, R. Steffen, Beau-Site Clinic Berne, Hirslanden Group, Switzerland, C. Tsigos, Department of Endocrinology, Metabolism and Diabetes Unit, Evgenidion Hospital, University of Athens Medical School, Athens, Greece, Kurt Widhalm, Department of Pediatrics, Nutrition and Metabolism, Medical University of Vienna, Vienna, Austria, for their valued co-author work on the first edition of the Interdisciplinary European Guidelines on Surgery of Severe Obesity, published in 2007/2008. We are grateful for their co-authorship of the first edition of the Guidelines, which provided substantial fundaments to the currently published Interdisciplinary European Guidelines on Metabolic and Bariatric Surgery and was still left unchanged in many parts. 
Fried et al.: Interdisciplinary European Guidelines on Metabolic and Bariatric Surgery

\section{References}

1 Finucane MM, et al: National, regional, and global trends in body-mass index since 1980: systematic analysis of health examination surveys and epidemiological studies with 960 country-years and 9.1 million participants. Lancet 2011;377:557-567.

2 World Health Organization (WHO)_Obesity. Available at www.euro.who.int/en/what-we-do/health-topics/ noncommunicable-diseases/obesity (last accessed September 9, 2013).

3 World Health Organization (WHO): Fact Sheet No.311 (updated March 2013). Available at www.who.int/mediacentre/factsheets/fs311/en/ (last accessed September 9, 2013).

4 Frühbeck G, Toplak H, Woodward E, Yumuk V, Maislos M, Oppert JM: Obesity: the gateway to ill health - an EASO position statement on a rising public health, clinical and scientific challenge in Europe. Obes Facts 2013; 6:117-120.

5 Flegal KM, Carroll MD, Kit BK, Ogden CL: Prevalence of obesity and trends in the distribution of body mass index among US adults, 1999-2010. JAMA 2012;307:491-497.

6 Ogden CL, Carroll MD, Kit BK, Flegal KM: Prevalence of obesity and trends in body mass index among US children and adolescents, 1999-2010. JAMA 2012;307:483-490.

7 Kelly T, Yang W, Chen CS, Reynolds K, He J: Global burden of obesity in 2005 and projections to 2030. Int J Obes (Lond) 2008;32:1431-1437.

-8 Finkelstein EA, Trogdon JG, Cohen JW, Dietz W: Annual medical spending attributable to obesity: payer- and service-specific estimates. Health Aff (Millwood) 2009;28:w822-w831.

-9 Frühbeck G. Obesity: screening for the evident in obesity. Nat Rev Endocrinol 2012;8:570-572.

$\checkmark 10$ Sjöström L: Review of the key results from the Swedish Obese Subjects (SOS) trial - a prospective controlled intervention study of bariatric surgery. J Intern Med 2013;273:219-234.

11 Berrington de Gonzalez A, Hartge P, Cerhan JR, Flint AJ, Hannan L, MacInnis RJ, Moore SC, Tobias GS, AntonCulver H, Freeman LB, Beeson WL, Clipp SL, English DR, Folsom AR, Freedman DM, Giles G, Hakansson N, Henderson KD, Hoffman-Bolton J, Hoppin JA, Koenig KL, Lee IM, Linet MS, Park Y, Pocobelli G, Schatzkin A, Sesso HD, Weiderpass E, Willcox BJ, Wolk A, Zeleniuch-Jacquotte A, Willett WC, Thun MJ: Body-mass index and mortality among 1.46 million white adults. N Engl J Med 2010;363:2211-2219.

-12 Flegal KM, Kit BK, Orpana H, Graubard BI: Association of all-cause mortality with overweight and obesity using standard body mass index categories: a systematic review and meta-analysis. JAMA 2013;309:71-82.

13 Neovius M, Narbro K, Keating C, Peltonen M, Sjöholm K, Agren G, Sjöström L, Carlsson L: Health care use during 20 years following bariatric surgery. JAMA 2012;308:1132-1141.

14 Fried M, Hainer V, Basdevant A, Buchwald H, Deitel M, Finer N, Greve JMM, Horber F, Mathus-Vliegen E, Scopinaro N, Steffen R, Tsigos C, Weiner R, Widhalm K: Interdisciplinary European guidelines on surgery of severe obesity. Obes Facts 2008;1:52-59.

-15 Lehman Center Weight Loss Surgery Expert Panel: Commonwealth of Massachusetts Betsy Lehman Center for Patient Safety and Medical Error Reduction Expert Panel on weight loss surgery: executive report. Obes Res 2005;13:205-305.

16 Sauerland S, Angrisani L, Belachew M, Chevallier JM, Favretti F, Finer N, et al: Obesity surgery: evidence based guidelines of the EAES. Surg Endosc 2005;19:200-221.

17 Maggard MA, Shugarman ML, Suttorp M, Maglione M, Sugerman HJ, Livingston EH, et al: Meta-analysis: surgical treatment of obesity. Ann Intern Med 2005;142:547-559.

18 Laville M, Romon M, Chavrier G, Guy-Grand B, Krempf M, Chevallier JM, et al: Recommendations regarding obesity surgery. Obes Surg 2005;15:1476-1480.

-19 Mechanick JI, Youdim A, Jones DB, Garvey WT, Hurley DL, McMahon MM, Heinberg LJ, Kushner R, Adams TD, Shikora S, Dixon JB, Brethauer S: AACE/TOS/ASMS Clinical practice guidelines for the perioperative nutritional, metabolic, and nonsurgical support of the bariatric surgery patient-2013 update: cosponsored by American Association of Clinical Endocrinologists, the Obesity Society, and American Society for Metabolic \& Bariatric Surgery. Endocr Pract 2013;19:337-372.

$\longrightarrow 20$ NIH Conference: Gastrointestinal surgery for severe obesity. Consensus development conference panel. Ann Intern Med 1991;115:956-961.

21 Ridley N: Expert panel on weight loss surgery - executive report. Obes Res 2005;13:206-226.

-22 Andersen T, Backer OG, Stokholm KH, Quaade F: Randomized trial of diet and gastroplasty compared with diet alone in morbid obesity. N Engl J Med 1984;310:352-356.

23 Andersen T, Stokholm KH, Backer OG, Quaade F: Long term (5-year) results after either horizontal gastroplasty or very low-calorie diet for morbid obesity. Int J Obes (Lond) 1988;12:277-284.

24 Karason K, Lindroos AK, Stenlof K, Sjostrom L: Relief of cardiorespiratory symptoms and increased physical activity after surgically induced weight loss: results from the Swedish Obese Subjects study. Arch Intern Med 2000;160:1797-1802.

25 Karlsson J, Sjostrom L, Sullivan M: Swedish Obese Subjects (SOS) an intervention study of obesity. Two-year follow-up of health-related quality of life (HRQL) and eating behavior after gastric surgery for severe obesity. Int J Obes Relat Metab Disord 1998;22:113-126.

-26 Fernandez AZ Jr, Demaria EJ, Tichansky DS, Kellum JM, Wolfe LG, Meador J: Multivariate analysis of risk factors for death following gastric bypass for treatment of morbid obesity. Ann Surg 2004;239:698-703. 
Fried et al.: Interdisciplinary European Guidelines on Metabolic and Bariatric Surgery

-27 Sjostrom CD, Peltonen M, Wedel H, Sjostrom L: Differentiated long-term effects of intentional weight loss on diabetes and hypertension. Hypertension 2000;36:20-25.

-28 Sjostrom CD, Lissner I, Wedel H, Sjostrom L: Reduction in incidence of diabetes, hypertension and lipid disturbances after intentional weight loss induced by bariatric surgery: the SOS Intervention Study. Obes Res 999; 7:477-484.

29 Christou NV, Sampalis JS, Liberman M, Look D, Auger S, McLean A, et al: Surgery decreases long-term mortality, morbidity, and health care use in morbidly obese patients. Ann Surg 2004;240:416-423.

30 Mun EC, Blackburn GL, Matthews JB: Current status of medical and surgical therapy for obesity. Gastroenterology 2001;120:669-681.

-31 Flum DR, Dellinger E: Impact of gastric bypass on survival: a population-based analysis. J Am Coll Surg 2004; 199:543-551.

32 American College of Endocrinology (ACE), American Association of Clinical Endocrinologists (AACE): AACE/ ACE Position Statement on the Prevention, Diagnosis and Treatment of Obesity. Jacksonville, American Association of Clinical Endocrinologists, 1998.

33 American Society for Bariatric Surgery, Society of American Gastrointestinal Endoscopic Surgeons: Guidelines for laparoscopic and open surgical treatment of morbid obesity. Obes Surg 2000;10:378-379.

34 Douketis JD, Feightner JW, Attia J, Feldman WF, with the Canadian Task Force on Preventive Health Care: Periodic health examination, 1999 update 1. Detection, prevention and treatment of obesity. CMAJ 1999;160: 513-525.

-35 International Federation for the Surgery of Obesity: Statement on patient selection for bariatric surgery. Obes Surg 1997; 7:41.

36 Lauterbach K, Westenhofer J, Wirth A, Hauner H: Evidenz-basierte Leitlinie zur Behandlung der Adipositas in Deutschland. Köln, Otto Hauser, 1998.

37 Msika S: Surgery for morbid obesity: 2. Complications. Results of a technologic evaluation by the ANAES. J Chir (Paris) 2003;140:4-21.

38 National Institute for Clinical Excellence: 2002 Guidance on the Use of Surgery to Aid Weight Reduction for People with Morbid Obesity (Technology Appraisal No 46). London, National Institute for Clinical Excellence, 2002.

39 Pontiroli AEW, Morabito A: Long-term prevention of mortality in morbid obesity through bariatric surgery. A systematic review and meta-analysis of trials performed with gastric banding and gastric bypass. Ann Surg 2011;253:484-487. Erratum in Ann Surg 2011;253:1056.

40 Buchwald H, Rudser KD, Williams SE, et al: Overall mortality, incremental life expectancy, and cause of death at 25 years in the program on the surgical control of the hyperlipidemias. Ann Surg 2010;251:1034-1040.

41 Padwal R, Klarenbach S, Wiebe N, et al. Bariatric surgery: a systematic review and network meta-analysis of randomized trials. Obes Rev 2011;12:602-621.

42 Garb J, Welch G, Zagarins S, et al: Bariatric surgery for the treatment of morbid obesity: a meta-analysis of weight loss outcomes for laparoscopic adjustable gastric banding and laparoscopic gastric bypass. Obes Surg 2009;19:1447-1455.

43 Valezi AC, Mali Junior J, de Menezes MA, et al: Weight loss outcome after silastic ring Roux-en Y gastric by-pass: 8 years of follow-up. Obes Surg 2010;20:1491-1495.

-44 Toouli J, Kow L, Ramos AC, et al: International multicenter study of safety and effectiveness of Swedish Adjustable Gastric Band in 1-, 3-, and 5-year follow-up cohorts. Surg Obes Relat Dis 2009;5:598-609.

45 Buchwald H, Estok R, Fahrbach K, et al: Weight and type 2 diabetes after bariatric surgery: systemic review and meta-analysis. Am J Med 2009;122:248-256.

46 Hofs $\emptyset$ D, Nordstrand N, Johnson LK, et al: Obesity-related cardiovascular risk factors after weight loss: a clinical trial comparing gastric bypass surgery and intensive lifestyle intervention. Eur J Endocrinol 2010;163; 735-745.

47 Hofsø D, Jenssen T, Bollerslev J, et al: Beta cell function after weight loss: a clinical trial comparing gastric bypass surgery and intensive lifestyle intervention. Eur J Endocrinol 2011;164:231-238.

48 Dixon JB, O’Brien PE, Playfair J, et al: Adjustable gastric banding and conventional therapy for type 2 diabetes. JAMA 2008;299:316-323.

49 Lee WJ, Chong K, Ser KH, et al: Gastric bypass vs. sleeve gastrctomy for type 2 diabetes mellitus. Arch Surg 2011;146:143-148.

50 Lee WJ, Wang W, Lee YC, et al: Effect of laparoscopic mini-gastric bypass for type 2 diabetes mellitus: comparison of BMI > 35 and < 35. J Gastrointest Surg 2008;12:945-952.

51 Cohen RV, Pinheiro JC, Schiavon CA, et al: Effects of gastric bypass surgery in patients with type 2 diabetes and only mild obesity. Diabetes Care 2012;35:1420-1428.

52 Choi J, Digiorgi M, Milone L, et al: Outcomes of laparoscopic adjustable gastric banding in patients with low body mass index. Surg Obes Relat Dis 2010;6:367-371.

-53 Serrot FJ, Dorman RB, Miller CJ, et al: Comparative effectiveness of bariatric surgery and nonsurgical therapy in adults with type 2 diabetes mellitus and body mass index $<35 \mathrm{~kg} / \mathrm{m}^{2}$. Surgery 2011;150:684-691.

54 Fried M, Ribaric G, Buchwald JN, et al: Metabolic surgery for the treatment of type 2 diabetes in patients with $\mathrm{BMI}<35 \mathrm{~kg} / \mathrm{m}^{2}$ : an integrative review of early studies. Obes Surg 2010;20:776-790.

55 Lee WJ, Chong K, Chen CY, et al: Diabetes remission and insulin secretion after gastric bypass in patients with body mass index $<35 \mathrm{~kg} / \mathrm{m}^{2}$. Obes Surg 2011;21:889-895. 
56 Demaria EJ, Winegar DA, Pate VW, et al: Early postoperative outcomes of metabolic surgery to treat diabetes from sites participating in the ASMBS bariatric surgery center of excellence program as reported in the Bariatric Outcomes Longitudinal Database. Ann Surg 2010;252:559-566.

57 Lee WJ, Ser KH, Chong K, et al: Laparoscopic sleeve gastrectomy for diabetes treatment in nonmorbidly obese patients: efficacy and change of insulin secretion. Surgery 2010;147:664-669.

58 Buse JB, Caprio S, Cefalu WT, et al: How do we define cure of diabetes? Diabetes Care 2009;32:2133-2135.

59 Maggard-Gibbons M, Maglione M, Livhits M et al: Bariatric surgery for weight loss and glycemic control in nonmorbidly obese adults with diabetes. JAMA 2013;309:2250-2261.

60 Ikramuddin S, Korner J, Lee W-J, et al: Roux-en-Y gastric bypass vs intensive medical management for the control of type 2 diabetes, hypertension, and hyperlipidemia. JAMA 2013;309:2240-2249.

61 Apovian CM, Baker C, Ludwig DS, Hoppin AG, Hsu C, Lenders C, et al: Best practice guidelines in pediatric/ adolescent weight loss surgery. Obes Res 2005;13:274-282.

62 Inge TH, Krebs NF, Garcia VF, Skelton JA, Guice KS, Strauss RS, et al: Bariatric surgery for severely overweight adolescents: concerns and recommendations. Pediatrics 2004;114:217-223.

63 Sugerman HJ, Sugerman EL, DeMaria EJ, Kellum JM, Kennedy C, Mowery Y, et al: Bariatric surgery for severely obese adolescents. J Gastrointest Surg 2003;7:102-107.

64 Dolan K, Creighton L, Hopkins G, Fielding G: Laparoscopic gastric banding in morbidly obese adolescents. Obes Surg 2003;13:101-104.

65 Stanford A, Glascock JM, Eid GM, Kane T, Ford HR, Ikramuddin S, et al: Laparoscopic Roux-en-Y gastric bypass in morbidly obese adolescents. J Pediatr Surg 2003;38:430-433.

66 Widhalm K, Dietrich S, Prager G: Adjustable gastric banding surgery in morbidly obese adolescents: experience with 8 patients. Int J Obes Relat Metab Disord 2004;28(suppl 3):42S-48S.

67 Silberhummer GR, Miller K, Kriwanek S, Widhalm K, Pump A, Prager G: laparoscopic adjustable gastric banding in adolescents: the Austrian experience. Obes Surg 2006;16:1062-1067.

68 Capella JF, Capella RF: Bariatric surgery in adolescence: is this the best age to operate? Obes Surg 2003;13: 826-832.

69 Patterson EJ, Urbach DR, Swanstrom LL: A comparison of diet and exercise therapy versus laparoscopic Rouxen-Y gastric bypass surgery for morbid obesity: a decision analysis model. J Am Coll Surg 2003;196:379-384.

70 Averbukh Y, Heshka S, El-Shoreya H, Flancbaum L, Geliebter A, Kamel S, et al: Depression score predicts weight loss following Roux-en-Y gastric bypass. Obes Surg 2003;13:833-836.

71 Ray EC, Nickels MW, Sayeed S, Sax HC: Predicting success after gastric bypass: the role of psychosocial and behavioral factors. Surgery 2003;134:555-564.

72 Charles SC: Psychiatric evaluation of morbidly obese patients. Gastroenterol Clin North Am 1987; 16:415-432. Gertler R, Ramsey-Stewart G: Pre-operative psychiatric assessment of patients presenting for gastric bariatric surgery (surgical control of morbid obesity). Aust N Z J Surg 1986;56:157-161. |

74 Guisado JA, Vaz FJ, Lopez-Ibor JJ, Lopez-Ibor MI, del Rio J, Rubio MA: Gastric surgery and restraint from food as triggering factors of eating disorders in morbid obesity. Int J Eat Disord 2002;31:97-100.

75 Sogg S, Mori DL: The Boston interview for gastric bypass: determining the psychological suitability of surgical candidates. Obes Surg 2004;14:370-380.

76 Ferraro DR: Preparing patients for bariatric surgery-the clinical considerations. Clin Rev 2004;14:57-63.

-77 Naef M, Sadowski C, de Marco D, Sabbioni M, Balsiger B, Laederach K, et al: Die vertikale Gastroplastik nach Mason zur Behandlung der morbiden Adipositas: Ergebnisse einer prospektiven klinischen Studie. Chirurg 2000;71:448-455.

78 Wiesner W, Schob 0, Hauser RS, Hauser M: Adjustable laparoscopic gastric banding in patients with morbid obesity: radiographic management, results, and postoperative complications. Radiology 2000;216:389-394.

79 Schumann R, Jones SB, Ortiz VE, Connor K, PulaiI I, Ozawa ET, et al: Best practice recommendations for anesthetic perioperative care and pain management in weight loss surgery. Obes Res 2005;13:254-266.

-80 O'Keeffe T, Patterson EJ: Evidence supporting routine polysomnography before bariatric surgery. Obes Surg 2004;14:23-26.

81 Sugerman HJ, Fairman RP, Baron PL, Kwentus JA: Gastric surgery for respiratory insufficiency of obesity. Chest 1986;90:81-86.

82 Sugerman HJ, Fairman RP, Sood RK, Engle K, Wolfe L, Kellum JM: Long-term effects of gastric surgery for treating respiratory insufficiency of obesity. Am J Clin Nutr 1992;55(suppl 2):597S-601S.

83 Miller K, Hell E: Laparoscopic surgical concepts of morbid obesity. Langenbecks Arch Surg 2003;388:375-384.

-84 Naef M, Sadowski C, de Marco D, Sabbioni M, Balsiger B, Laederach K, et al: Die vertikale Gastroplastik nach Mason zur Behandlung der morbiden Adipositas: Ergebnisse einer prospektiven klinischen Studie. Chirurg 2000;71:448-455.

85 Gonzalez R, Bowers SP, Venkatesh KR, Lin E, Smith CD: Preoperative factors predictive of complicated postoperative management after Roux-en-Y gastric bypass for morbid obesity. Surg Endosc 2003;17:1900-1914.

86 Frey WC, Pilcher J: Obstructive sleep-related breathing disorders in patients evaluated for bariatric surgery. Obes Surg 2003;13:676-683.

-87 Sharaf RN, Weinshel EH, Bini EJ, Rosenberg J, Ren CJ: Radiologic assessment of the upper gastrointestinal tract: does it play an important preoperative role in bariatric surgery? Obes Surg 2004;14:313-317.

88 Jaffin BW, Knoepflmacher P, Greenstein R: High prevalence of asymptomatic esophageal motility disorders among morbidly obese patients. Obes Surg 1999;9:390-395. 
Fried et al.: Interdisciplinary European Guidelines on Metabolic and Bariatric Surgery

89 Frigg A, Peterli R, Zynamon A, Lang C, Tondelli P: Radiologic and endoscopic evaluation for laparoscopic adjustable gastric banding: preoperative and follow-up. Obes Surg 2001;11:594-599.

90 Greenstein RJ, Nissan A, Jaffin B: Esophageal anatomy and function in laparoscopic gastric restrictive bariatric surgery: implications for patient selection. Obes Surg 1998;8:199-206.

-91 Verset D, Houben JJ, Gay F, Elcheroth J, Bourgeois V, Van Gossum A: The place of upper gastrointestinal tract endoscopy before and after vertical banded gastroplasty for morbid obesity. Dig Dis Sci 1997;42:2333-2337.

-92 Saltzman E, Anderson W, Apovian CM, Hannah B, Alison C, Diana C-D, et al: Criteria for patient selection and multidisciplinary evaluation and treatment of the weight loss surgery patient. Obes Res 2005;13:234-243.

93 Sogg S, DeAnna LM: Psychosocial Evaluation for bariatric surgery: the Boston interview and opportunities for intervention. Obes Surg 2009;19:369-377.

$\$ 94$ Heinberg LJ, Ashton K, Windover A: Moving beyond dichotomous psychological evaluation: The Cleveland Clinic Behavioral Rating System for Weight Loss Surgery. Surg Obes Relat Dis. 2010;6:185-190.

95 Greenberg I, Sogg S, Perna FM: Behavioral and psychological care in weight loss surgery: best practice update. Obesity. 2009;17:880-884.

-96 Mahony D: Psychological assessments of bariatric surgery patients. Development, reliability, and exploratory factor analysis of the PsyBari. Obes Surg 2011;21:1395-1406.

97 Fabricatore AN, Crerand CE, Wadden TA, et al: How do mental health professionals evaluate candidates for bariatric surgery? Survey results. Obes Surg 2005;15:567-573.

98 Peacock JC, Zizzi SJ: An assessment of patient behavioral requirements pre- and post-surgery at accredited weight loss surgical centers. Obes Surg 2011;21:1950-1957.

99 Bauchowitz AU, Gonder-Frederick LA, Olbrisch ME, et al: Psychosocial evaluation of bariatric surgery candidates: a survey of present practices. Psychosom Med 2005;67:825-832.

100 van Hout GC, Jakimowicz JJ, Fortuin FA, Pelle AJ, van Heck GL: Weight loss and eating behavior following vertical banded gastroplasty. Obes Surg 2007;17:1226-1234.

101 Kofman, MD, Lent MR, Swencionis C, et al: Maladaptive eating patterns, quality of life, and weight outcomes following gastric bypass: results of an internet survey. Obesity (Silver Spring) 2010;18:1938-1943.

102 Rutledge T, Groez LM, Savu M, et al: Psychiatric factors and weight loss patterns following gastric bypass surgery in a veteran population. Obes Surg 2011;21:29-35.

103 Odom J, Zalesin KC, Washington TL, et al.: Behavioral predictors of weight regain after bariatric surgery. Obes Surg 2010;20:349-356.

104 Colles SL, Dixon JB, O'Brien PE: Grazing and loss of control related to eating: two high-risk factors following bariatric surgery. Obesity (Silver Spring) 2008;16:615-622. Erratum in Obesity (Silver Spring) 2011;19:2287.

105 Kruseman M, Leimgruber A, Zumbach F, et al: Dietary, weight, and psychological changes among patients with obesity, 8 years after gastric bypass. J Am Diet Assoc 2010;110:527-534.

106 deZwaan M, Mitchell JE, Howell LM, et al: Characteristics of morbidly obese patients before gastric bypass surgery. Compr Psychiatry 2003;44:428-434.

107 Hsu LK, Benotti PN, Dwyer J, et al: Nonsurgical factors that influence the outcome of bariatric surgery: a review. Psychosom Med 1998;60:338-346.

108 Guisado Macias JA, Vaz Leal FJ: Psychopathological differences between morbidly obese binge eaters and nonbinge eaters after bariatric surgery. Eat Weight Dis 2003;8:315-318.

109 Sabbioni ME, Dickson MH, Eychmueller S, et al: Intermediate results of health related quality of life after vertical banded gastroplasty. Int J Obes Relat Metab Disord 2002;26:277-280.

110 Toussi R, Fujioka K, Coleman KJ: Pre-and postsurgery behavioral compliance, patient health, and postbariatric surgical weight loss. Obesity (Silver Spring) 2009;17:966-1002.

111 Sarwer DB, Wadden TA, Fabricatore AN: Psychosocial and behavioral aspects of bariatric surgery. Obes Res 2005;13:639-648.

112 de Zwaan M, Hilbert A, Swan-Kremeier L, et al: Comprehensive interview assessment of eating behavior 18-35 months after gastric bypass surgery for morbid obesity. Surg Obes Relat Dis 2010;6:79-87.

113 White MA, Kalarchian M, Masheb RM, et al: Loss of control over eating predicts outcomes in bariatric surgery patients: a prospective, 24-month follow-up study. J Clin Psychiatry 2010;71:175-184.

114 Sarwer DB, Dilks RJ, West-Smith L: Dietary intake and eating behavior after bariatric surgery: threats to weight loss maintenance and strategies for success. Surg Obes Rel Dis 2011;7:644-651.

115 Ashton K, Heinberg L, Windover A, et al: Positive response to binge eating intervention enhances postsurgical weight loss and adherence. Surg Obes Relat Dis 2011;7:315-320.

116 Korner J, Inabnet W, Febres G, et al: Prospective study of gut hormone and metabolic changes after adjustable gastric banding and Roux-en-Y gastric bypass. Int J Obes (Lond) 2009;33:786-795.

117 Laferrere B, Teixeira J, McGinty J, et al: Effect of weight loss by gastric bypass surgery versus hypocaloric diet on glucose and incretin levels in patients with type 2 diabetes. J Clin Endocrinol Metab 2008;93:2479-2485.

118 Bose M, Teixeira J, Olivan B, et al: Weight loss and incretin responsiveness improve glucose control independently after gastric bypass surgery. J Diabetes 2010;2:47-55.

119 Vidal J, Ibarzabal A, Romero F, et al: Type 2 diabetes mellitus and the metabolic syndrome following sleeve gastrectomy in severely obese subjects. Obes Surg 2008;18:1077-1082.

$\checkmark 120$ Leslie DB, Dorman RB, Serrot FJ, et al: Efficacy of the Roux-en-Y gastric bypass compared to medically managed controls in meeting the American Diabetes Association composite end point goals for management of type 2 diabetes mellitus. Obes Surg 2012;22:367-374. 
Fried et al.: Interdisciplinary European Guidelines on Metabolic and Bariatric Surgery

121 Carlsson LM, Peltonen M, Ahlin S, et al: Bariatric surgery and prevention of type 2 diabetes in Swedish obese subjects. N Engl J Med 2012;367:695-704.

122 Arterburn DE, Bogart A, Sherwood NE, et al: A multisite study of long-term remission and relapse of type 2 diabetes mellitus following gastric bypass. Obes Surg 2013;23:93-102.

123 Laferrere B: Effect of gastric bypass surgery on the incretins. Diabetes Metab 2009;35:513-517.

124 Kashyap SR, Daud S, Kelly KR, et al: Acute effects of gastric bypass versus gastric restrictive surgery on betacell function and insulinotropic hormones in severely obese patients with type 2 diabetes. Int J Obes (Lond) 2010;34:462-471.

125 Peterli R, Wolnerhanssen B, Peters T, et al: Improvement in glucose metabolism after bariatric surgery: comparison of laparoscopic Roux-en-Y gastric bypass and laparoscopic sleeve gastrectomy: a prospective randomized trial. Ann Surg 2009;250:234-241.

126 Mingrone G, Castagneto-Gissey L: Mechanisms of early improvement/resolution of type 2 diabetes after bariatric surgery. Diabetes Metab 2009;35:518-523.

127 Briatore L, Salani B, Andraghetti G, et al: Beta-cell function improvement after biliopancreatic diversion in subjects with type 2 diabetes and morbid obesity. Obesity (Silver Spring) 2010;18:932-936.

128 Briatore L, Salani B, Andraghetti G, et al: Restoration of acute insulin response in T2DM subjects 1 month after biliopancreatic diversion. Obesity (Silver Spring) 2008;16:77-81.

129 Talebpour M, Amoli BS: Laparoscopic total gastric vertical plication in morbid obesity. J Laparoendosc Adv Surg Tech A 2007; 17:793-798.

130 Skrekas G, Antiochos K, Stafyla VK: Laparoscopic gastric greater curvature plication: results and complications in a series of 135 patients. Obes Surg 2011;21:1657-1663.

-131 Ramos A, Galvao Neto M, Galvao M, Evangelista LF, Campos JM, Ferraz A: Laparoscopic greater curvature plication: initial results of an alternative restrictive bariatric procedure. Obes Surg 2010;20:913-918.

132 Brethauer SA, Harris JL, Kroh M, et al: Laparoscopic gastric plication for treatment of severe obesity. Surg Obes Relat Dis 2011;7:15-22.

133 National Institute for Health and Clinical Excellence (NICE) Interventional Procedure Guidance 432: Laparoscopic gastric plication for the treatment of severe obesity. 2012. Available at http://publications.nice.org.uk/ laparoscopic-gastric-plication-for-the-treatment-of-severe-obesity-ipg 432 (last accessed September 9, 2013).

134 Fried M, Dolezalova K, Buchwald JN, et al. Laparoscopic greater curvature plication (LGCP) for the treatment of morbid obesity in a series of 244 patients. Obes Surg 2012;22:1298-1307.

135 Sánchez-Pernaute A, Rubio MA, Pérez-Aguirre ME, et al: Single-anastomosis duodeno-ileal bypass with sleeve gastrectomy: metabolic improvement and weight loss in first 100 patients Surg Obes Relat Dis 2012; doi:10.1016/j.soard.2012.07.018.

136 Reoch J, Mottillo S, Shimony A, et al: Safety of laparoscopic vs open bariatric surgery: a systematic review and meta-analysis. Arch Surg 2011;146:1314-1322.

137 Kelly J, Tarnoff M, Shikora S, Thayer B, Jones DB, Forse RA, et al: Best practice recommendations for surgical care in weight loss surgery. Obes Res 2005;13:227-233.

138 Brolin RE: Bariatric surgery and long-term control of morbid obesity. JAMA 2002;288:2793-2796.

139 Mun EC, Blackburn GL, Matthews JB: Current status of medical and surgical therapy for obesity. Gastroenterology 2001;120:669-681.

140 Murr MM, Balsiger BM, Kennedy FP, Mai JL, Sarr MG: Malabsorptive procedures for severe obesity: comparison of pancreaticobiliary bypass and very very long limb Roux-en-Y gastric bypass. J Gastrointest Surg 1999;3: 607-612.

141 Scopinaro N, Gianetta E, Adami GF, Friedman D, Traverso E, Marinari GM, et al: Biliopancreatic diversion for obesity at eighteen years. Surgery 1996;119:261-268.

142 Scopinaro N, Marinari GM, Camerini G: Laparoscopic standard biliopancreatic diversion: technique and preliminary results. Obes Surg 2002;12:362-365.

143 Howard L, Malone M, Michalek A, Carter J, Alger S, Van Woert J: Gastric bypass and vertical banded gastroplasty - a prospective randomized comparison and 5-year follow-up. Obes Surg 1995;5:55-60.

144 van Dielen FM, Soeters PB, de Brauw LM, Grewe JW: Laparoscopic adjustable gastric banding versus open vertical banded gastroplasty: a prospective randomized trial. Obes Surg 2005;15:1292-1298.

145 Brolin RE, Kenler HA, Gorman JH, Cody RP: Long-limb gastric bypass in the superobese. A prospective randomized study. Ann Surg 1992;215:387-395.

146 Podnos YD, Jimenez JC, Wilson SE, Stevens CM, Nguyen NT: Complications after laparoscopic gastric bypass: a review of 3464 cases. Arch Surg 2003;138:957-961.

147 Perugini RA, Mason R, Czerniach DR, Novitsky YW, Baker S, Litwin DEM, et al: Predictors of complication and suboptimal weight loss after laparoscopic Roux-en-Y gastric bypass: a series of 188 patients. Arch Surg 2003; 138:541-545

148 Nguyen NT, Rivers R, Wolfe BM: Factors associated with operative outcomes in laparoscopic gastric bypass. J Am Coll Surg 2003;197:548-555.

149 Ren CJ, Weiner M, Allen JW: Favorable early results of gastric banding for morbid obesity: the American experience. Surg Endosc 2004;18:543-546.

150 Rubenstein RB: Laparoscopic adjustable gastric banding at a US center with up to 3-year follow-up. Obes Surg 2002;12:380-384. 
Fried et al.: Interdisciplinary European Guidelines on Metabolic and Bariatric Surgery

151 O'Brien PE, Dixon JB, Brown W, Schachter LM, Chapman L, Burn AJ, et al: The laparoscopic adjustable gastric band (Lap-Band): a prospective study of medium-term effects on weight, health and quality of life. Obes Surg 2002;12:652-660.

152 Spivak H, Favretti F: Avoiding postoperative complications with the LAP-BAND system. Am J Surg 2002; 184(suppl 2):31S-37S.

153 Belachew M, Belva PH, Desaive C: Long-term results of laparoscopic adjustable gastric banding for treatment of morbid obesity. Obes Surg 2002;12:564-568.

154 DeMaria EJ, Sugerman HJ: A critical look at laparoscopic adjustable silicone gastric banding for surgical treatment of morbid obesity: does it measure up? Surg Endosc 2000;14:697-699.

155 Favretti F, Cadiere GB, Segato G, Himpens J, Busetto L, De Marchi F, et al: Laparoscopic adjustable silicone gastric banding (Lap-Band): how to avoid complications. Obes Surg 1997;7:352-358.

156 Fried M, Miller K, Kormanova K: Literature review of comparative studies of complications with Swedish band and Lap-Band. Obes Surg 2004;14:256-260.

157 Fried M, Peskova M, Kasalicky M: Assessment of the outcome of laparoscopic nonadjustable gastric banding and stoma adjustable gastric banding: surgeon's and patient's view. Obes Surg 1998;8:45-48.

158 Hall JC, Watts JM, O’Brien PE, Dunstan RE, Walsh JF, Slavotinek AH, et al: Gastric surgery for morbid obesity. the Adelaide Study. Ann Surg 1990;211:419-427.

159 Laws HL, Piantadosi S: Superior gastric reduction procedure for morbid obesity: a prospective, randomized trial. Ann Surg 1981;193:334-340.

160 Bajardi G, Ricevuto G, Mastrandrea G, Branca M, Rinaudo G, Cali F, et al: Surgical treatment of morbid obesity with biliopancreatic diversion and gastric banding: report on an 8-year experience involving 235 cases. Ann Chir 2000;125:155-162.

161 Chapman AE, Kiroff G, Game P, Foster B, O’Brien PE, Ham J, et al: Laparoscopic adjustable gastric banding in the treatment of obesity: a systematic literature review. Surgery 2004;135:326-351.

162 Dolan K, Hatzifotis M, Newbury L, Fielding G: A comparison of laparoscopic adjustable gastric banding and biliopancreatic diversion in superobesity. Obes Surg 2004;14:165-169.

163 Lee WJ, Chong K, Ser KH, et al: Gastric bypass vs. sleeve gastrctomy for type 2 diabetes mellitus. Arch Surg 2011;146:143-148.

164 Lee WJ, Wang W, Lee YC, et al: Effect of laparoscopic mini-gastric bypass for type 2 diabetes mellitus: comparison of BMI > 35 and < 35. J Gastrointest Surg 2008;12:945-952.

165 Cohen RV, Pinheiro JC, Schiavon CA, et al: Effects of gastric bypass surgery in patients with type 2 diabetes and only mild obesity. Diabetes Care 2012;35:1420-1428.

166 Choi J, Digiorgi M, Milone L, et al: Outcomes of laparoscopic adjustable gastric banding in patients with low body mass index. Surg Obes Relat Dis 2010;6:367-371.

167 Scopinaro N, Adami GF, Papadia FS, Camerini G, et al: Effects of biliopanceratic diversion on type 2 diabetes in patients with BMI 25 to 35. Ann Surg 2011;253:699-703

168 Ciangura C, Bouillot JL, Lloret-Linares C, Poitou C, Veyrie N, Basdevant A, Oppert JM: Dynamics of change in total and regional body composition after gastric bypass in obese patients. Obesity (Silver Spring) 2010;18: 760-765.

169 Jones DB, Provost DA, DeMaria EJ, Smith CD, Morgenstern L, Schirmer B: Optimal management of the morbidly obese patient SAGES appropriateness conference statement. Surg Endosc 2004;18:1029-1037.

170 American Society for Bariatric Surgery: Bariatric surgery: ASBS guidelines. 2004. www.lapsurgery.com/ BARIATRIC\%20SURGERY/ASBS.htm (last accessed September 9, 2013) .

171 Society of American Gastrointestinal Endoscopic Surgeons: Guidelines for institutions granting bariatric privileges utilizing laparoscopic techniques. SAGES and the SAGES Bariatric Task Force. Surg Endosc 2003;17: 2037-2040.

172 Flum DR, Dellinger EP: Impact of gastric bypass operation on survival: a population-based analysis. J Am Coll Surg 2004;199:543-551.

173 Schauer P, Ikramuddin S, Hamad G, Gourash W: The learning curve for laparoscopic Roux-en-Y gastric bypass is 100 cases. Surg Endosc 2003;17:212-215.

174 Wittgrove AC, Clark GW: Laparoscopic gastric bypass, Roux-en-Y-500 patients: technique and results with 3-60 months follow-up. Obes Surg 2000;10:233-239.

175 Higa KD, Boone KB, Ho T, Davies OG: Laparoscopic Roux-en-Y gastric-bypass for morbid obesity: technique and preliminary results of our first 400 patients. Arch Surg 2000;135:1029-1033.

176 Courcoulas A, Schuchert M, Gatti G, Luketich J: The relationship of surgeon and hospital volume to outcome after gastric bypass surgery in Pennsylvania: a 3-year summary. Surgery 2003;134:613-623.

177 Sarwer DB, Moore RH, Spitzer JC, et al: A pilot study investigating the efficacy of postoperative dietary counseling to improve outcomes after bariatric surgery. Surg Obes Relat Dis 2012;8:561-568.

178 Kulick D, Hark L, Deen D: The bariatric surgery patient: a growing role for registered dietitians. J Am Diet Asoc 2010;110:593-599.

179 Ziegler O, Sirveaux MA, Brunaud L, et al: Medical follow up after bariatric surgery: nutritional and drug issues. General recommendations for the prevention and treatment of nutritional deficiencies. Diabetes Metab 2009; 35:544-557.

180 Faria, SL: Dietary protein intake and bariatric surgery. Obes Surg 2011;21:1798-1805. 
Fried et al.: Interdisciplinary European Guidelines on Metabolic and Bariatric Surgery

181 Raftopoulos I: Protein intake compliance with morbidly obese patients undergoing bariatric surgery and its effect on weight loss and biochemical parameters. SOARD 2011;7:733-742.

182 Billy H, Okerson T: Changes in body composition following gastric bypass or gastric banding. AACE 21st Annual Scientific and Clinical Congress, May 23-27, 2012, Philadephia PA; Abstract \#1315.

183 Bavaresco M, Paganini S, Pereira Lima T, et al: Nutritional course of patients submitted to bariatric surgery. Obes Surg 2010;20:716-721.

184 Andreu A, Moize V, Rodriguez L, et al: Protein intake, body composition, and protein status following bariatric surgery. Obes Surg 2010;20:1509-1515.

185 Moize VL, Pi-Sunyer X, Mochari H, et al: Nutritional pyramid for post-gastric bypass patients. Obes Surg 2010; 20:1133-1141.

186 Padwal R, Brocks D, Sharma AM: A systematic review of drug absorption following bariatric surgery and its theoretical implications. Obes Rev 2010;11:41-50.

187 Miller AD, Smith KM: Medication and nutrient administration considerations after bariatric surgery. Am J Health Syst Pharm 2006;63:1852-1857.

188 Ceppa EP, Ceppa DP, Omotosho PA, et al: Algorithm to diagnose etiology of hypoglycemia after Roux-en-Y gastric bypass for morbid obesity: case series and review of the literature. Surg Obes Relat Dis 2012;8:641-647.

189 Cui Y, Elahi D, Andersen DK: Advances in the etiology and management of hyperinsulinemic hypoglycemia after Roux-en-Y gastric bypass. J Gastrointest Surg 2011;15:1879-1888.

190 Bernard B, Kline GA, Service FJ: Hypoglycemia following upper gastrointestinal surgery: case report and review of the literature. BMC Gastroenterol 2010;10:77-80.

191 Spanakis E, Gragnoli C: Successful medical management of status post-Roux-en-Y-gastric-bypass hyperinsulinemic hypoglycemia. Obes Surg 2009;19:1333-1334.

192 Moreira RO, Moreira RBM, Machado NAM, et al: Post-prandial hypoglycemia after bariatric surgery: pharmacological treatment with verapamil and acarbose. Obes Surg 2008;18:1618-1621.

193 Geerts WH, Bergqvist D, Pineo GF, et al: Prevention of venous thromboembolism: American College of Chest Physicians Evidence-Based Clinical Practice Guidelines (8th edition). Chest 2008;133:381S-453S.

194 Magee CJ, Barry J, Javed S, et al: Extended thromboprophylaxis reduces incidence of postoperative venous thromboembolism in laparoscopic bariatric surgery. Surg Obes Relat Dis 2010;6:322-325.

195 Raftopoulos I, Martindale C, Cronin A, et al: The effect of extended post-discharge chemical thromboprophylaxis on venous thromboembolism rates after bariatric surgery: a prospective comparison trial. Surg Endosc 2008;22:2384-2391.

196 Winegar DA, Sherif B, Pate V, et al: Venous thromboembolism after bariatric surgery performed by Bariatric Surgery Center of Excellence Participants: analysis of the Bariatric Outcomes Longitudinal Database. Surg Obes Relat Dis 2011;7:181-188.

197 The ASMBS Clinical Issues Committee: ASMBS Guideline on the prevention and detection of gastrointestinal leak after gastric bypass including the role of imaging and surgical exploration. Surg Obes Relat Dis 2009;5: 293-296.

198 Warschkow R, Tarantino I, Folie P, et al: C-reactive protein 2 days after laparoscopic gastric bypass surgery reliably indicates leaks and moderately predicts morbidity. J Gastrointest Surg 2012;16:1128-1135.

199 Lyass S, Khalili TM, Cunneen S, et al: Radiological studies after laparoscopic Roux-en-Y gastric bypass: routine or selective? Am Surg 2004;70:918-921.

200 Carussi LR, Turner MA, Conklin RC, et al: Roux-en-Y gastric bypass surgery for morbid obesity: evaluation of postoperative extraluminal leaks with upper gastrointestinal series. Radiology 2006;238:119-127.

201 Miller K, Hell E: Laparoscopic surgical concepts of morbid obesity. Langenbecks Arch Surg 2003;388:375-384.

202 Laville M, Romon M, Chavrier G, Guy-Grand B, Krempf M, Chevallier JM, et al: Recommendations regarding obesity surgery. Obes Surg 2005;15:1476-1480.

203 Shen R, Dugay G, Rajaram K, Cabrera I, Siegel N, Ren CJ: Impact of patient follow-up on weight loss after bariatric surgery. Obes Surg 2004;14:514-519.

204 Favretti F, O’Brien PE, Dixon JB: Patient management after LAP-BAND placement. Am J Surg 2002;184(suppl 2):38S-41S.

205 Busetto L, Pisent C, Segato G, De Marchi F, Favretti F, Lise M, et al: The influence of a new timing strategy of band adjustment on the vomiting frequency and the food consumption of obese women operated with laparoscopic adjustable silicone gastric banding (LAP-BAND). Obes Surg 1997;7:505-512.

-206 Rabkin RA, Rabkin JM, Metcalf B, Lazo M, Rossi M, Lehman-Becker LB: Nutritional markers following duodenal switch for morbid obesity. Obes Surg 2004;14:84-90.

207 Ledikwe JH, Smiciklas-Wright H, Mitchell DC, Jensen GL, Friedmann JM, Still CD: Nutritional risk assessment and obesity in rural older adults: a sex difference. Am J Clin Nutr 2003;77:551-558.

208 Ledikwe JH, Smiciklas-Wright H, Mitchell DC, Miller CK, Jensen GL: Dietary patterns of rural older adults are associated with weight and nutritional status. J Am Geriatr Soc 2004;52:589-595.

209 MacLean LD, Rhode B, Shizgal HN: Nutrition after vertical banded gastroplasty. Ann Surg 1987;206:555-563.

210 Hamoui N, Anthone G, Crookes PF: Calcium metabolism in the morbidly obese. Obes Surg 2004;14:9-12.

211 Faintuch J, Matsuda M, Cruz ME, Silva MM, Teivelis MP, Garrido AB Jr, et al: Severe proteincalorie malnutrition after bariatric procedures. Obes Surg 2004;14:175-181.

212 Baltasar A, Serra C, Perez N, Bou R, Bengochea M: Clinical hepatic impairment after the duodenal switch. Obes Surg 2004;14:77-83. 
Fried et al.: Interdisciplinary European Guidelines on Metabolic and Bariatric Surgery

213 Boylan LM, Sugerman HJ, Driskell JA: Vitamin E, vitamin B-6, vitamin B-12, and folate status of gastric bypass surgery patients. J Am Diet Assoc 1988;88:579-585.

-214 Cannizzo F Jr, Kral JG: Obesity surgery: a model of programmed undernutrition. Curr Opin Clin Nutr Metab Care 1998;1:363-368.

-215 Hamoui N, Kim K, Anthone G, Crookes PF: The significance of elevated levels of parathyroid hormone in patients with morbid obesity before and after bariatric surgery. Arch Surg 2003;138:891-897.

216 Skroubis G, Sakellaropoulos G, Pouggouras K, Mead N, Nikiforidis G, Kalfarentzos F: Comparison of nutritional deficiencies after Roux-en-Y gastric bypass and after biliopancreatic diversion with Roux-en-Y gastric bypass. Obes Surg 2002;12:551-558.

217 Slater GH, Ren CJ, Siegel N, Williams T, Barr D, Wolfe B, et al: Serum fat-soluble vitamin deficiency and abnormal calcium metabolism after malabsorptive bariatric surgery. J Gastrointest Surg 2004;8:48-55.

218 Halverson JD: Micronutrient deficiencies after gastric bypass for morbid obesity. Am Surg 1986;52:594-598.

219 Avinoah E, Ovnat A, Charuzi I: Nutritional status seven years after Roux-en-Y gastric bypass surgery. Surgery 1992;111:137-142.

220 Brolin RE, Gorman RC, Milgrim LM, Kenler HA: Multivitamin prophylaxis in prevention of postgastric bypass vitamin and mineral deficiencies. Int J Obes Relat Metab Disord 1991;15:661-667.

221 Rhode BM, Arseneau P, Cooper BA, Katz M, Gilfix BM, MacLean LD: Vitamin B-12 deficiency after gastric surgery for obesity. Am J Clin Nutr 1996;63:103-109.

222 Schilling RF, Gohdes PN, Hardie GH: Vitamin B12 deficiency after gastric bypass surgery for obesity. Ann Intern Med 1984;101:501-502.

223 Simon SR, Zemel R, Betancourt S, Zidar BL: Hematologic complications of gastric bypass for morbid obesity. South Med J 1989;2:1108-1110.

224 Brolin RE, Gorman JH, Gorman RC, Petschenik AJ, Bradley LJ, Kenler HA, et al: Are vitamin B12 and folate deficiency clinically important after Roux-en-Y gastric bypass? J Gastrointest Surg 1998;2:436-442.

-225 Halverson JD: Metabolic risk of obesity surgery and long term follow-up. Am J Clin Nutr 1992;55(suppl 2):602S-605S.

226 Goode LR, Brolin RE, Chowdhury HA, Shapses SA: Bone and gastric bypass surgery: effects of dietary calcium and vitamin D. Obes Res 2004;12:40-47.

-227 Coates PS, Fernstrom JD, Fernstrom MH, Schauer PR, Greenspan SL: Gastric bypass surgery for morbid obesity leads to an increase in bone turnover and a decrease in bone mass. J Clin Endocrinol Metab 2004;89:10611065.

228 Shaker JL, Norton AJ, Woods MF, Fallon MD, Findling JW: Secondary hyperparathyroidism and osteopenia in women following gastric exclusion surgery for obesity. Osteoporos Int 1991;1:177-181.

229 Abu-Abeid S, Keidar A, Gavert N, Blanc A, Szold A: The clinical spectrum of band erosion following laparoscopic adjustable silicone gastric banding for morbid obesity. Surg Endosc 2003;17:861-863.

230 Jones KB Jr: Revisional bariatric surgery-safe and effective. Obes Surg 2001;11:183-189.

231 Weber M, Muller MK, Michel JM, Belal R, Horber F, Hauser R, et al: Laparoscopic Roux-en-Y gastric bypass, but not rebanding, should be proposed as rescue procedure for patients with failed laparoscopic gastric banding. Ann Surg 2003;238:827-834.

232 Dolan K, Fielding G: Bilio pancreatic diversion following failure of laparoscopic adjustable gastric banding. Surg Endosc 2004;18:60-63.

233 Chevallier JM, Zinzindohoue F, Douard R, Blanche JP, Berta JL, Altman JJ, et al: Complications after laparoscopic adjustable gastric banding for morbid obesity: experience with 1,000 patients over 7 years. Obes Surg 2004; 14:407-414.

234 Iovino P, Angrisani L, Tremolaterra F, Nirchio E, Ciannella M, Borrelli V, et al: Abnormal esophageal acid exposure is common in morbidly obese patients and improves after a successful Lap-band system implantation. Surg Endosc 2002;16:1631-1635.

235 Niville E, Dams A: Late pouch dilation after laparoscopic adjustable gastric and esophagogastric banding: incidence, treatment, and outcome. Obes Surg 1999;9:381-384.

236 Sanyal AJ, Sugerman HJ, Kellum JM, Engle KM, Wolfe L: Stomal complications of gastric bypass: incidence and outcome of therapy. Am J Gastroenterol 1992;87:165-169.

237 Weiner R, Theodoridou S, Weiner S: Failure of laparoscopic sleeve gastrectomy - further procedure? Obes Facts 2011;4(suppl 1):42-46.

-238 Barba CA, Butensky MS, Lorenzo M, Newman R: Endoscopic dilation of gastroesophageal anastomosis stricture after gastric bypass. Surg Endosc 2003;17:416-420.

239 Schauer PR, Ikrammudin S, Gourash W, Ramanathan R, Luketich J: Outcomes after laparoscopic Roux-en-Y gastric bypass for morbid obesity. Ann Surg 2000;232:515-529.

240 Spaulding L: Treatment of dilated gastrojejunostomy with sclerotherapy. Obes Surg 2003;13:254-257.

241 Anthone GJ, Lord RV, DeMeester TR, Crookes PF: The duodenal switch operation for the treatment of morbid obesity. Ann Surg 2003;238:618-628.

242 Bloomberg RD, Urbach DR: Laparoscopic Roux-en-Y gastric bypass for severe gastroesophageal reflux after vertical banded gastroplasty. Obes Surg 2002;12:408-411.

243 Cowan GS Jr: Bariatric surgical utterances: need they be dogmatic? Obes Surg 1999 9:3-4.

244 Cowan GS Jr: Obligations of the bariatric surgeon. Obes Surg 2000;10:498-501. 